\title{
Property Rights Institutions and Investment ${ }^{1}$
}

\author{
Jahangir Saleh \\ St.Mary's College of MD
}

\begin{abstract}
This paper examines the channels through which alternative property rights institutions affect investment. These institutions are defined by a society's enforced laws, regulations, governance mechanisms and norms concerning the use of resources. A transaction cost framework is used to analyze the incentive impact of various types of property rights, liability rules, and rules regarding contracts. This framework is used to discuss the legal and cultural conditions necessary for the formation of productivity-enhancing organizations and the proper role of government in providing the infrastructure for private investment. A brief section examines the role of cultural and religious norms in determining the economic effectiveness of legal systems, with a focus on Islamic countries. The final section evaluates empirical approaches used to discover the specific ways property rights structures affect investment and growth.
\end{abstract}

\section{World Bank Policy Research Working Paper 3311, May 2004}

The Policy Research Working Paper Series disseminates the findings of work in progress to encourage the exchange of ideas about development issues. An objective of the series is to get the findings out quickly, even if the presentations are less than fully polished. The papers carry the names of the authors and should be cited accordingly. The findings, interpretations, and conclusions expressed in this paper are entirely those of the authors. They do not necessarily represent the view of the World Bank, its Executive Directors, or the countries they represent. Policy Research Working Papers are available online at http://econ.worldbank.org.

\footnotetext{
${ }^{1}$ I am grateful to Shahrokh Fardoust, Jean Jacques Dethier, Rick Messick and Mustapha Nabli for their very valuable and insightful comments.
} 


\section{Table of Contents}

$\begin{array}{ll}\text { Introduction } & \text { p. } 3\end{array}$

$\begin{array}{ll}\text { I. Property Rights and Incentives } 5 & \text { p. }\end{array}$

$\begin{array}{ll}\text { A. General Framework } & \text { p. } 7\end{array}$

$\begin{array}{ll}\text { B. Taxonomy of Property Rights } & \text { p. } 9\end{array}$

i. Open Access Common Resources p. 9

ii. Restricted Access Common Resources p. 10

iii. Usufructs p. 11

$\begin{array}{ll}\text { iv. Private Property Rights } & \text { p. } 12\end{array}$

v. Restrictions on Private Property Rights p. 13

$\begin{array}{ll}\text { C. Protecting Entitlements with Liability Rules } & \text { p. } 15\end{array}$

$\begin{array}{ll}\text { II. Transaction Costs, Contracts and Organizations } & \text { p. } 17\end{array}$

$\begin{array}{ll}\text { A. Sources of Transaction Costs } & \text { p. } 18\end{array}$

$\begin{array}{ll}\text { B. Enforcement Costs } & \text { p. } 21\end{array}$

$\begin{array}{ll}\text { C. Firms and Markets } & \text { p. } 22\end{array}$

$\begin{array}{ll}\text { D. Influence Costs } & \text { p. } 23\end{array}$

III. Government Regulation and Government Provision p. 25

IV. Culture, Religion and Property Rights p. 30

$\begin{array}{ll}\text { V. Empirical Approaches and Conclusion } & \text { p. } 36\end{array}$

A. Cross Country Studies p. 36

B. The Comparative Institutionalist Approach p. 38

$\begin{array}{ll}\text { C. The Micro-Econometric Approach } & \text { p. } 39\end{array}$

$\begin{array}{ll}\text { Bibliography } & \text { p. } 43\end{array}$ 


\section{Introduction}

This paper discusses property rights, the contractual arrangements made possible by those rights, and their effects on investment and growth. Property rights are broadly defined as the set of laws and customs, or formal and informal rules, that determine how individuals may gain access to resources and the range of possible uses they may make of them. They include rights and obligations with respect to the use, maintenance and improvement of resources, the rules of exchange or contract, and rules of liability when a particular use of a resource by one individual comes into conflict with the rights of other individuals. Property rights determine who gets to make decisions about resource use, and define the incentives faced by individuals with claims against these resources. The structure of incentives created by a society's property rights regime will determine the degree of specialization in productive activities and hence the overall productivity of an economy. If property rights are improperly defined or left ambiguous and unenforced, resources will be wasted as people try to capture or defend their claims to resources.

The paper is divided into five sections. The first section outlines an overall framework indicating the possible channels through which property rights affect investment. It also provides a general taxonomy of types of property rights institutions and their effects on individual incentives for production and investment. It examines why different property rights arrangements may be established and the conditions under which these arrangements may or may not be efficient.

The second section discusses the links between property rights, transaction costs and contracts. How property rights are defined and enforced determines the range of possible transactions people may make with each other to take advantage of the benefits of specialization and teamwork. The legal regime defining and enforcing property rights and rules of liability affects transaction costs and thus the likelihood that resources will be directed to higher-valued uses. This section examines various dimensions of transaction costs and how property, contract and liability law may be structured to reduce them.

Often complex production activities can only be achieved through the creation of organizations or

firms, which may be conceived as networks of contracts that allow specific resource owners, the owners of capital, to obtain control over a variety of other resources, particularly labor. The key message of this section is that firms can reduce many of the transaction costs associated with the complex market exchanges necessary to take advantage of economies of scale and scope [Coase 1937]. But the ability of 
private entrepreneurs to create efficient-sized firms requires stable property rights and contract enforcement, well-functioning credit and input markets, the absence of intrusive external interference in the firms' affairs, and low-cost access to necessary public goods. Success depends on being able to form efficient and enforceable contracts with outside suppliers, employees and creditors. We will discuss how the rules and restrictions governing these contracts will determine the size and nature of the activities of firms and the level and efficiency of their investments.

The third section focuses on the role of the government in promoting or hindering efficient private investments. Governments help provide the legal environment necessary for the functioning of markets and firms. A government may be considered as the set of organizations that define and enforce property rights, enact rules and regulations, and, in many instances, produce goods and services that the private sector may not be willing to supply in socially optimum quantities. The key message of this section is that government regulations, and the willingness and ability of the state to enforce them, tend to redefine, clarify or obfuscate property rights, as do different degrees of state enforcement of contracts. Regulations that clarify property rights, reduce transaction costs and encourage competition will promote growth while regulations that create unnecessary transaction costs in the private sector will impair its growth. Similarly, state production of goods and services may be complementary to, or an inefficient substitute for, private production.

The fourth section discusses the importance of cultural factors in promoting or retarding investment. The cultural environment defines peoples' beliefs about right and wrong, and thus their willingness to follow or violate social rules. Strong beliefs about the morality of specific rules will affect individuals' willingness to comply with them and even to incur personal costs to privately enforce them. Religion is the central cultural institution in many countries and affects individual beliefs about the validity or morality of legal rules and social norms. In recent decades religious influence has been rising in many countries, particularly in Islamic countries where the Sharia or Islamic law has become increasingly influential. The Sharia has a well developed body of laws about property and contracts and there is some controversy over whether these codes hinder or promote commercial and industrial development in the countries that adhere to them. This section will evaluate some of these arguments. Does the application of the Islamic tradition to law tend to promote efficient property rights arrangements, or do countries trying to 
make their commercial laws consistent with Sharia doctrine face greater barriers to growth? What kinds of investments are encouraged or discouraged by the institutions affected by this tradition?

The final section of the paper examines some of the attempts to test empirically the general framework discussed above and to measure the impact of different institutional structures on economic performance.

\section{Property Rights and Incentives}

Property rights represent the formal and informal claims and obligations of individuals against the resources of a society. The way property rights are defined and enforced will affect not only the efficiency of resource use, and the levels and types of investments made, but also the allocation of risk and the distribution of income. Property rights systems evolve for complex reasons as individuals and groups vie for resources and struggle to reach cooperative agreements to reduce conflict, to promote production or to control risk. Thus the property rights that eventually emerge in any society need not be and most often are not wealth maximizing. Other factors such as reduction of risk or the creation and maintenance of a certain distribution of wealth and power may also be determining factors. These aspects are often in conflict. Wealth maximization requires that resources be controlled by those who can extract maximum value from them, while reducing risk often involves sharing output and reduced incentives for effort and investment. The emergence of private property rights may create more risk for individuals but better incentives. However the full potential of these incentives for investment and innovation will not come to fruition unless it is possible to mitigate some of this risk through diversification and insurance. Otherwise riskaverse individuals will be induced to undertake many risk-mitigating actions that might limit potential growth-enhancing investments as individuals refrain from exposing their fortunes to loss in high risk but high return activities. That is why limited liability laws and bankruptcy statutes, by limiting the risks to individual investors, are considered important for encouraging investment in these kinds of investments.

Property rights may also emerge (or be imposed) to promote a certain distribution of power and wealth. A ruling coalition may be reluctant to adopt wealth maximizing rules if such rules would reduce the wealth and power of members of the coalition. Devising and enforcing Pareto-superior rules are often not possible due to high political transaction costs, the costs of forming new coalitions, negotiating with other 
coalitions and enforcing new sets of more efficient rules [Eggerston 1990; North 1990]. Thus Douglass North writes that institutions (which he defines as the societal rules constraining individual behavior) "were-and are- always a mixed bag of those that induce productivity increase and those that reduce productivity." 2 The degree to which property rights and other institutions promote productive activity and discourage redistributive and unproductive activities will determine the overall productivity and growth of an economy.

Property rights are often complex and attenuated in various ways. The complexity of property rights is due in part to the varied nature of different resources and the multiplicity of their uses and effects. Measuring the multidimensional potential effects of different uses on different individuals explains, in part, why property rights are often not defined and enforced in a complete way [Barzel 1989]. If actions and their effects were easily observable and verifiable, then it would be possible, in principle, for those in authority to define rights and obligations in such a precise way that those who use resources would bear the full costs and benefits of their actions and thus would be induced to act efficiently. However, since the uses and effects of resource use cannot be measured at low cost, property rights are often ambiguous and certain resources or their uses are left ambiguous and effectively in the public domain. This means that people will have incentives to try to "capture" their potential value by expending resources in predatory or defensive actions or in simply overusing and wasting these particular resources. ${ }^{3}$

Property rights are always in constant flux. Who maintains or acquires which rights depends on an individual's own efforts to protect a given right (say by securing boundaries against trespass), collective enforcement, and the efforts of others to capture one's rights. ${ }^{4}$ Property rights may be obtained through usurpation or agreement. Once obtained, they must be protected by collective and private enforcement mechanisms.

Individual claims against resources always involve some combination of communal and private property rights. Most often, individuals will need to combine the resources under their control and reach agreements with other resource "owners" to achieve reasonable productivity. For example, a farmer who has acquired the right to cultivate a piece of land, and has private ownership of a few farm animals, will

\footnotetext{
${ }^{2}$ North, Ibid.

${ }^{3}$ Barzel, p. 3 .

${ }^{4}$ Ibid. p.2.
} 
need access to water, tools, seeds, the labor of others, and access to grazing fields, in order to realize the full potential of his resources. Water may be available as an open-access resource or as a regulated common resource; tools and seeds may be borrowed from neighbors or bought in a market; help from others may be obtained through a market for labor or through communal conventions and norms of reciprocal aid; and grazing fields may be obtained through communal use rights. How rights are defined with respect to each of these resources, who controls them and how their use can be transferred to others, will determine the structure of incentives and the efficiency of resource use. The benefits of defining and enforcing rights more precisely rises as populations expand, economies grow and resources become more scarce. Whether in fact such restructuring of rights occurs will depend on the relative abilities of potential winners and losers for effective political action. What follows is a brief outline of a general framework describing the various channels through which property rights affect investment. Following that, a brief classification of types of property rights and the circumstances under which such rights might produce economically efficient outcomes will be presented.

\section{A. General Framework}

Property rights determine investment by affecting its expected returns. Because property rights are complex and multidimensional, they affect expected returns through a number of distinct but interrelated channels. These include the following:

1. Security of property rights is the most often cited channel for promoting investment. More secure rights generally lead to lower expected expropriation and higher net returns. Following Besley [1995] we can think of this expectation of expropriation as an expected (random) tax on returns. Investments may be expropriated through theft, fraud, confiscation or taxation. Insecure property rights also affect the expected variability of expropriation. For any given expected expropriation level, there may be higher or lower variability. Uncertainty of expropriation affects the uncertainty of returns and tends to discourage investment for risk-averse decision makers. When property rights are insecure, potentially less efficient investments may also be undertaken as a means to strengthen the security of property rights. [See Deininger and Feder 2000]. 
2. A second factor affecting investment is the degree of transferability of property, through gift, bequest, rent or sale. Higher transferability may increase the expected returns from investment in many ways. First, it gives greater utility of returns to the investor by allowing him to bequeath a larger estate to his heirs. It also means that the value of improvements in property can be realized through sale. And finally, when circumstances warrant property can be transferred to those who can make better use of it, that is, those who can make more efficient investments. The possibility for transfer of resource rights will not be desirable if there is the possibility of negative external effects on others in the community. Hence resources might be made inalienable or require the consent of the authorities in the community. As economic development proceeds and contracts with the world outside a community become more lucrative, such constraints on transfer might retard investment and productivity. [see Binswanger et. al. 1995].

3. The types of investments that can be undertaken depend on the ability of owners to borrow capital at relatively low cost. The ability to use property as collateral reduces the cost of borrowing and encourages investment. This ability depends on the degree to which the legal system and social norms protect and enforce financial contracts. Formalization and registration of property rights generally reduce the costs of making and enforcing financial contracts by making it easier to transfer assets in case of default [DeSoto 1989, 2000]. In addition, formal titles to property lower the costs to lenders for determining the credit-worthiness of borrowers.

4. The return to investment also depends on the degree to which property owners can obtain access to common property resources and public goods at reasonable cost. Laws, regulations and customs determining the conditions for access to common property affect the returns to investment by allowing fuller utilization of resource complementarities. Similarly, if governments are able to provide the requisite public goods and infrastructure, the returns to private investments will rise.

5. Returns to investment also depend on the ability to make deals with other property owners such as customers, creditors, potential shareholders, workers and suppliers. Such deals can be made at relatively low cost if private competitive markets for these goods and services exist. But informational asymmetries, the possibilities for hidden actions and strategic behavior, and potential monopolization may make such costs high or threaten the existence of such markets. 
Whether markets exist and how effectively they function in providing resources at competitive cost depend on the institutions (laws, regulations and customs) that have evolved or been established to reduce uncertainty, foster trust and prevent monopolization.

6. The exercise of property rights by one or more people may impose costs on others and high transaction costs may prevent an efficient resolution of these potential conflicts through negotiation. Private investments in redistributive activities or in activities that involve significant negative externalities tend to reduce the returns and value of property to others. Institutions that facilitate the internalization of externalities and reduce the returns to redistributive (or rentseeking) activities tend to strengthen overall property rights and increase the returns to productive investment. Therefore government regulations, court-imposed liability rules and externality taxes that are socially cost effective (where the benefits of the harms prevented exceed the costs of implementation and compliance) may increase growth-enhancing investments. Ideally, we would need to specify a social welfare function in order to determine social costs and benefits.

A society's property rights institutions include all of its enforced laws, regulations and customs that affect resource use. These institutions together will help determine the degree to which costs and benefits of actions are internalized and thus the incentives for productive investment. Different historical and technological circumstances will require different sets of institutions and property rights to generate growth-enhancing investments. Under each set of circumstances, strictly private rights should be given to some resources while other resources should combine elements of common property and regulation. Some resources should be protected by liability rules while other resources should be protected by property rules or full rights of exclusion. What follows is a general taxonomy of types of property rights and the conditions under which each might be appropriate.

\section{B. Brief Taxonomy of Property Rights}

\section{Open-Access Communal Resources}

Open-access communal resources are resources that may be used by members of a community in an unrestricted way. Such property rights are appropriate under two conditions: when a resource is non- 
scarce (when demand is less than availability at zero price); and when a resource is scarce but the costs of exclusion (that is, the costs of defining boundaries or other ways of limiting access) exceed the benefits of exclusion (reductions in the harmful effects of overuse). Open access resources include many of the resources in the ocean, community parks, sidewalks, roads and certain kinds of knowledge. Public goods in general, with high costs of exclusion and little rivalry in use, fall into this category. Even if there is rivalry or subtractability in use, it may still be efficient to maintain open access rules if the nature of the resource is such that exclusion is technically very costly. Highways during rush hour are an example of such an open access resource. $^{5}$

Exclusion may sometimes be technically possible but undesirable because of non-rivalry or low marginal costs of use. Goods subject to increasing returns (natural monopolies) fall in this category. The government may have to subsidize the production or regulate the use of such goods to ensure access at low cost. However if creating exclusive private rights will create sufficiently better incentives for innovation and the creation of new products, then it may be appropriate to define and enforce exclusive private rights. Such circumstances provide the rationale for private ownership of natural monopolies and for the creation of intellectual property rights. Intellectual property rights will be harmful if they are too broadly defined so that the marginal benefits of restricted access (new knowledge and inventions) are less than the marginal costs (reduced access to products with high marginal value but low marginal costs of use).

\section{Restricted Access Common Resources}

As demand for scarce or "rivalrous" common resources increases, the costs of open access may become too great relative to the benefits. Some social mechanism encouraging conservation becomes desirable to avoid the familiar "tragedy of the commons" [Hardin, 1968]. Social norms and traditions may evolve to induce people to limit use at various margins and to invest in the upkeep of the resource, thus internalizing the externalities to some extent. In addition, some collective governance authority may be created to impose and enforce specific rules and regulations restricting use [Ostrom 1990]. Enforcement of these rules will be easier if violations are readily observable, and are more likely to be "reported" and

\footnotetext{
${ }^{5}$ Even though Barzel [1989] claims that the gasoline tax is an indirect and imperfect but perhaps efficient way of excluding people from overuse of roads.
} 
punished. Thus the customary rules of "local commons" are more likely to be effective than rules imposed on more extensive commons at the regional, national and international level. [Seabright, 1993; Ostrom, 1990]. Nevertheless there may be many circumstances when sophisticated and costly monitoring and enforcement mechanisms may be worthwhile if the costs of non-enforcement are high enough.

The incentive problems associated with managing common resources apply not only to resources traditionally subject to communal ownership, such as grazing lands, fisheries, aquifers, wells and oil reserves, but also to sets of resources committed to common management by voluntary (and sometimes involuntary and coercive) agreements, such as the resources under the control of households, firms, nonprofit organizations and governments. Section three below will discuss the nature of organizations, the reasons for their formation, and the methods with which they deal with their particular incentive problems.

\section{Usufructs}

When the costs associated with communal governance rise sufficiently (or the costs of drawing and enforcing boundaries fall sufficiently), it may become efficient to divide up a resource into different segments under individual control. Such rights to use (but not transfer) land or other resources are called usufruct rights. ${ }^{6}$ Compared to a communal arrangement it may be easier to defend boundaries against trespassers and monitoring of users becomes less important. Many of the externalities associated with communal use are internalized. While nuisance externalities may still be imposed on neighbors, the cost of negotiating adjustments with them may be low in settings where accepted social norms and customs help define the range of acceptable actions and help the parties settle disputes [Ellickson 1986].

Usufructs may still result in underinvestment and overexploitation since some of the benefits of investment are not transferable to potential buyers or to one's descendants, while some of the costs of overexploitation may be passed on to future users. Nevertheless usufructs may be preferable to full private ownership under certain conditions. These conditions are most likely to occur when a resource is not very susceptible to improvement by investment or damage by use. Usufructs are appropriate if the possibility of transfer will inflict expected harm to third parties by enough to counteract the potential gains from transfer. Thus if economic circumstances change such that the expected gains from transfer (including exchange)

\footnotetext{
${ }^{6}$ If transfer rights are included it may be said that full private property rights exist, even though, as will be seen below, private property is never absolute and almost always involves many restrictions and obligations.
} 
increase sufficiently, it may be more efficient to convert usufructs into transferable private property. In European history usufructs in land were gradually transformed into private property as capitalism grew and took hold [See Hicks 1969]. In modern developing countries similar transformations have occurred as commerce has expanded. In certain developing countries land titles are uncertain and possession is accompanied by usufruct rights. The theory suggests that when commercial possibilities expand sufficiently to significantly increase the potential gains from transfer, these properties should be transformed into private property. However if tribal and other local connections are sufficiently important, such transfer rights might pose a threat to the community and transferability might be restricted.

Note that the concept of use-rights is not confined to land. Anytime a resource is made inalienable we have a kind of usufruct, the right to use but not to sell. Rose-Ackerman [1985] observes that inalienability is and has been pervasive in all societies. The efficiency rationale for inalienability is considered a second-best response to market failures arising from externalities, asymmetries of information and coordination costs. ${ }^{7}$ Inalienability rules may even make markets work better in certain circumstances. Modern laws preventing owners or their agents from giving away assets during bankruptcy proceedings may help bolster the confidence of creditors in getting repaid, thus improving the workings of credit markets. $^{8}$

\section{Private Property Rights}

With the growth of market opportunities, the costs of having usufructs and prohibiting sale may become too great and alienability might be allowed. With full private property rights, incentives become stronger while greater opportunities are opened up for more complex contractual exchanges and greater specialization. All of this of course presumes the existence of competition among private owners.

Full private property rights, however constrained, generally involve the freedom from expropriation, the right of sale or transfer, and the right to use a property as collateral. When transfer is possible the property may be sold to individuals who may be able to use it in a better way or to extract more income from it. This means that the original owner will be able to recoup the value of any

\footnotetext{
${ }^{7}$ Rose-Ackerman, p. 200.

${ }^{8}$ Ibid. p. 202.
} 
investments or improvements he has made in the property in case he decides to pursue better opportunities. Similarly if the property can be used as collateral owners may borrow resources to take advantage of investment opportunities.

De Soto [2000] provides a more detailed analysis of the importance of "formalization" of private property rights in complex market economies. By formal property he means property rights that are documented and protected by the state. Assets would be registered, with their most important attributes (including restrictions such as easements and encumbrances) written down and recorded. Thus ownership is made more secure and transaction costs are reduced as strangers are able to more easily trace and validate the attributes of assets without actually having to see them. The flow of information and communication about assets and their potential uses improves. Formal property is more easily acceptable as collateral, allowing owners to mortgage their assets to obtain loans for investment. When the legal system allows easy and secure transfer of assets, opportunities for new investments are opened up and assets and resources get guided to their most valued uses. ${ }^{9}$

\section{Restrictions on Private Property Rights}

Despite the obvious private incentive advantages of absolute and fully secure private property rights for many assets, restrictions are almost always placed on the rights of private owners due to the potential harms that particular uses may inflict on others. If these harms could be precisely measured at low cost, precise fees could be imposed to internalize the externalities. If harms cannot be precisely measured, then quantity regulations on more measurable proxies for the externalities may be more appropriate.

[Glaeser and Shleifer, 2001].

The right of eminent domain is another example of a restriction of a private property right. The right of eminent domain allows the government to "take" private property for valuable public purposes often in return for "reasonable compensation." ${ }^{10}$ Eminent domain is considered necessary because of the

\footnotetext{
${ }^{9}$ As is well known, what are considered "most-valued uses" depend in large part on the initial allocation of endowments and rights.

${ }^{10}$ Fischel [1995] has an excellent discussion of what are known as "regulatory takings." Changes in government regulations may severely depress the values of certain private properties making it analogous to the actual physical taking of private property. Fischel addresses the issue of compensation for such "takings." Of course in normal circumstances people whose property values are diminished by government
} 
high transaction costs that might occur if the government tried to voluntarily purchase all the properties it needs for a particular project. One holdout could potentially block a valuable project or make it prohibitively expensive. Potential sellers might be tempted to hold out in the hopes of obtaining a better price. Potential hold-up problems are in fact one major cause of high transaction costs, especially when many parties are involved. Allowing the government to force the sale may thus be potentially efficient. Requiring compensation for the original owners is not technically necessary from a Kaldor-Hicks perspective. In this view takings are justified if the social benefits outweigh the foregone benefits to the original owners, and the payment of compensation might even be considered to be an unnecessary administrative expense. According to the Pareto criterion, however, compensation would be necessary to increase the likelihood that no one is made worse off. Compensation is also desirable if it constrains government officials from undertaking inefficient and low-valued projects. Finally compensation might be considered to be ethically fair in that the costs of public projects are not disproportionately borne by particular individuals and are more widely shared through the tax system. [See Shavell 2003]. In this context, taking property without compensation involves what Michelman calls "demoralization costs" or "the sum of utility losses to losers and their sympathizers specifically from the realization that no compensation is offered" as well as the resulting disincentive effects and social disruption costs that may arise. $^{11}$

Eminent domain in fact is just one example of situations where the community allows intrusion into the property rights of others, with or without the payment of compensation. In such cases we may say that property is protected by a liability rule rather than a property rule. How property is protected depends in large measure on the potential for alternative uses, the externalities that the use of the property may entail, and on the transaction costs associated with bargaining and enforcing agreements over the uses and externalities.

regulations are not compensated for their losses due in part to the huge bureaucratic costs that would be involved.

${ }^{11}$ Cited in Fischel, pp. 144-145. Michelman proposes that compensation should be paid if the net social benefits of the taking exceed the administrative costs of compensation, and if demoralization costs exceed settlement costs. Otherwise compensation should not be paid. This rule should theoretically apply to all kind of government takings. 


\section{Protecting Entitlements with Liability Rules or Property Rules}

In their celebrated work on conflicting use or externality situations, Calabresi and Melamed [1972] analyze the rationales for different methods of protecting property rights. Once an individual is given an entitlement to use a resource, society must decide on the type of protection it will give in case the entitlement is infringed. A property rule punishes trespassers with criminal penalties. With a property rule, the only way for someone to gain access to someone else's property is through voluntary exchange or transfer. Sometimes, however, it might be more desirable to protect an entitlement with a liability rule. A liability rule protects against trespass by imposing damages.

According to Calabresi and Melamed, the reason for protecting property rights with different rules is the existence of transaction costs. If transaction costs are zero, externalities and conflicting uses will be internalized and we obtain the very Coasian result that it will not matter by which rule property is protected: in both cases the parties involved will end up reaching an agreement and using resources in the most efficient way. However with high transaction costs, the choice of a particular rule will matter. Recall that Coase [1960] showed that if transaction costs are positive and there is a conflict over resource use, courts should try to give the property rights to the party who values it most, or make liable the party who can avoid the externality at lower cost. Similarly Calabresi and Melamed show that if transaction costs are high, the particular way entitlements are protected is important in guiding resources to their highest valued uses. If initial endowments do not rest with those who value them the most, the only way to get resources to the "right" people is through either a voluntary or an involuntary transfer. High transaction costs will often preclude voluntary transfers. One way to allow an efficient "involuntary" transfer is to allow the party that potentially values the resource more highly to "take" it in return for the payment of compensatory damages. If a reasonably precise value for these damages could be determined by courts or regulators at low cost, then liability rule protection would lead to the efficient result. If not, then liability rule protection might open the door to inefficient abuse of property rights and much predatory and defensive action.

The power of eminent domain is considered a liability rule because it allows the government to take private property, usually on condition that it pays appropriate (market value) compensation. ${ }^{12}$ Liability

\footnotetext{
${ }^{12}$ Governments may even transfer their eminent domain authority to private firms as when the U.S. government granted eminent domain rights to railroad companies in the $19^{\text {th }}$ century.
} 
rules are also important when property rights are violated accidentally or inadvertently. The requirement that compensation be paid may induce more precaution and care by the potential violator. If no compensation is required for such harms, we may say that the property right over that particular "attribute" is given to the potential injurer. This may be desirable if the expected harm is low relative to the expected benefits and if requiring compensation would involve high administrative costs.

Bebchuk [2001] builds on Calabresi and Melamed's analysis of entitlement rules by examining how different specifications of entitlements affect the ex ante investment decisions of the parties involved in a conflicting use situation, by affecting the ex post distribution of surplus (defined as the sum of the net returns to the parties). Note that in C\&M's model, following Coase, the ex post distribution of surplus would not affect resource allocation or the equilibrium levels of activities of the various parties (assuming zero wealth effects). Bebchuk assumes that ex ante bargaining is difficult so that complete multi-period contracts specifying all actions cannot be enacted and enforced, but that ex post bargaining over any payments one side must make to the other is costless. He also assumes that bargaining power of each party depends on the initial entitlements they have obtained. As a result, the ex post distribution of surplus will be affected by the ex ante actions of the (two) parties, encompassing investments in productive, polluting and harm-reducing activities. An entitlement rule which affects ex post distribution of surplus will affect ex ante incentives to invest. ${ }^{13}$

By way of illustration, Bebchuk considers various scenarios involving two companies, a resort (R) and a factory $(\mathrm{F})$, both needing to use a body of water, one for entertainment, the other for pollution. He shows what will happen with different entitlement rules given some reasonable assumptions about ex post bargaining power. If $\mathrm{R}$ is given a property right to enjoin $\mathrm{F}$ from polluting, then $\mathrm{R}$ will over-invest, while $\mathrm{F}$ will under-invest. If $\mathrm{R}$ is given liability rule protection, it will over-invest by even more than it would under a property rule because it would have no incentives to undertake harm reducing investments; under this rule, F will have efficient incentives to invest because it will be able to keep the value of its investments ex post. If $\mathrm{F}$ has property rule protection, it will tend to over-invest, while $\mathrm{R}$ will tend to under-invest.

Bebchek concludes that the optimum entitlement rule depends on many parameters involving the propensities of the parties to over-invest or under-invest in various circumstances. He also suggests that the

${ }^{13}$ Bebchuk, pp.2-5 
menu of alternative rules should be expanded to include liability rules based on "super-compensatory damages" and "under-compensatory damages."14 Thus, for example, if $\mathrm{R}$ has liability rule protection and is therefore likely to over-invest, then under-compensatory damages might produce a better result. Another significant factor that has to be taken into account is the informational requirements placed on the courts or regulatory agencies. In general, property rule protections have far less informational requirements than liability rule protections. But property rule protection for resources might prove to be socially costly if the initial allocation of entitlements rests with those who have low-valued uses and if transaction costs are high. Here a liability rule requiring the payment of compensatory damages might be better. ${ }^{15}$ But as seen above, fully compensatory damage payments might be inefficient in a bilateral investment situation since the potential victim might not undertake adequate harm-reducing investments. A general externality tax on the "injurer" might achieve a better result (if administratively feasible at low cost) by inducing both the injurer and the victim to internalize the external costs involved. Here the victim will not receive any payment and thus will be induced to undertake cost-effective harm reducing investments to protect himself.

\section{Transaction Costs, Contracts and Organizations}

As indicated above, any initial distribution of property rights is unlikely to be fully efficient. Resources may not be under the control of those who value them most, or who have the skills, knowledge and initiative to extract the most value out of them. Potentially, there are three basic ways to move toward a more efficient arrangement: voluntary exchanges of entitlements or contract; involuntary taking by private or public actors; or a spontaneous evolution in conventions and norms relating to the use patterns of a resource.

Contracts are mutually binding promises to undertake explicit or implicit actions over time. They are a means to promote specialization, teamwork and specialized (relationship-specific) investments. The kinds of contracts private owners of resources or their agents may make with each other will depend on the

\footnotetext{
${ }^{14}$ Ibid. p. 50.

${ }^{15}$ Such was the logic of the court in the famous case of Boomer v. Atlantic Cement Co. [1970]. Neighbors of the cement factory had sought injunctive relief according to the usual remedy under common law. But the court ruled that such a remedy could potentially shut down the plant at great cost to itself and the community. Thus the plant was allowed to continue operation subject to the payment of damages to the community.
} 
laws and norms governing contracts. Some potential contracts will be allowed and some will not; some will be enforced if breached by one of the parties while others will not. Ideally the institutions of society will promote all mutually beneficial contracts with net gains to society (those contracts where the net gains to the parties involved, including transaction costs, are greater than any external costs associated with the contract), while discouraging contracts that may have net costs to society.

In general, all potentially mutually beneficial contracts and exchanges of property rights must overcome transaction costs to be implemented. Transaction costs are barriers to the formation of contracts. The study of transaction costs has formed the foundation of the law and economics movement and the analysis of institutions. ${ }^{16}$ We have already seen how transaction costs may provide guidance with respect to the kinds of property rights and entitlements that should be enforced. Analysis of transaction costs is also of central importance in determining the nature of contracts and the forms of cooperation possible in an economy. Coase [1960] showed that when transaction costs are zero, resources will be allocated efficiently no matter how property rights are delineated (as long as they are clearly defined in the law). This of course uses the concept of transaction costs in a very broad and all encompassing way. The importance of Coase's insight is that since transaction costs are almost never zero, and often quite high, legal rules defining property and contract rights will have significant effects on resource allocation.

\section{A. Sources of Transaction Costs}

Transaction costs include the costs of searching for the right partners, measuring the attributes and qualities of the goods and services to be exchanged, bargaining over the terms and conditions of a contract, establishing appropriate monitoring mechanisms, and enforcing an agreement. As previously indicated, these costs are all essentially due to the high costs of information and the possibilities for opportunism. Hidden information and hidden actions are possible because of the inherent limitations of human cognition. This means that contracts are always made in an environment of uncertainty and risk. In a general market setting the existence of asymmetries of information may lead to adverse selection and the thinning out of certain markets [Akerlof 1970]. Rules to disclose information may result in fewer mistakes and the

\footnotetext{
${ }^{16}$ See R. Coase, 1960. Williamson traces the notion of transaction costs to John R. Commons. See Williamson, 1985.
} 
overcoming of adverse selection problems. But such rules are feasible only if third parties (a court or government agency or arbitrator) can observe and verify whether information that is disclosed is in fact accurate or false and misleading. ${ }^{17}$

Measuring the quality of performance in a contract is often inherently complex and cannot be fully specified in all dimensions. Contracts always involve implicit understandings that cannot be fully specified and enforced. The inevitable uncertainties and gaps will lead to potential conflicts if one party does not meet the expectations of the other. Social norms and trust relations based on reputation and repeat dealings help overcome some of these problems and become increasingly important if the formal institutions of contract law are absent. [See World Development Report 2002, Ch. 9]. This is why bazaars in the Middle East and elsewhere can carry on so much business without formal contracts. The merchants, tradesmen, moneylenders and craftsmen seek each other out to form client-type relationships which involve repeat dealings, thus using personalized reputation as a means to trust each other. Some informal arbitration possibilities by colleagues and elders ensure participants of relatively easy settling of disputes. Outsiders would have a hard time breaking into this environment. ${ }^{18}$ But these kinds of personalized transactions are inherently limited. Formal rules enforced by government are needed for contracts involving strangers. Generally these formal rules (such as widely accepted default rules or conditions for breach) should complement the informal rules based on the social norms of specific cultures. Such complementarities in laws and norms encourage the formation of more complex contracts and make it possible to overcome some of the moral hazard and information problems hindering the development of many markets. [WDR 2002, Ch.9].

Another source of bargaining cost is the inherent difficulty of foreseeing all potential contingencies that might arise in an uncertain world and specifying the appropriate adjustments if such contingencies were to occur. If certain unforeseen contingencies occur one party might find it beneficial to breach or renegotiate the contract. But it may be difficult to determine if this is an opportunistic breach or one based on real mitigating factors which have made it impossible or impractical to carry out the contract. Opportunism is a danger inherent in all contracts since contracts are formed to allow reliance and other

${ }^{17}$ Fraud may be distinguished from nondisclosure. Fraud is when a piece of information is deliberately misrepresented. Nondisclosure becomes fraud if there is a legal rule requiring that a particular piece of information be revealed.

${ }^{18}$ See Clifford Geertz, 1979. 
specific investments that have lower values outside the contract, that is, in the market, than within the contract. This creates the temptation to "hold up" the other party by threatening non-compliance in an attempt to appropriate more of the potential surplus of the contract.

To maximize social wealth, the law must allow for efficient breaches of contract while discouraging opportunistic breaches. Efficient breach means that the sum of net gains to all the parties involved from breaching is positive. This often means that one party will stand to gain more from breach than other parties will lose. If transactions costs are low we would expect the parties to reach a mutually beneficial agreement and void the contract, with appropriate damage payments so that both parties end up better off. ${ }^{19}$ We would want contract law to be structured so as make transaction costs as low as possible Analogous to the protection of property rights, courts can use a property rule or a liability rule to protect contracts. ${ }^{20}$ Courts may rule for "specific performance" or require that the breaching party pay some damages. Specific performance is analogous to a property rule protection, while damage awards are analogous to liability rules. With expectation damages a contractor will breach if he is willing to pay the promisee an amount equal to what he expected to get out of the contract. Hence he will breach only if it efficient to do so, when both parties would be made better off. But determining the appropriate level of "expectation damages" is likely to be costly to the courts. In addition, full expectation damages might lead to too much reliance investment by the contractee. To prevent over-reliance and to lower administrative costs, damages may need to be based on the principle of "reasonable" reliance. [Shavell 2003]. Ulen [1984] argues that when transaction costs among the parties are low it is better for courts to require specific performance of the contract. The parties would then reach some mutually beneficial accommodation. The ruling by the court would simply be in the form of a clarification of property rights in the contract. The problem is that if the parties have come to court it is probably a good indication that transaction costs are high. Some easily accessible, predictable and low-cost arbitration mechanism may be one means of lowering transaction costs.

\footnotetext{
${ }^{19}$ Sometimes a party may be allowed to breach without paying damages, as in cases involving impossibility, frustration of purpose, or mutual mistake.

${ }^{20}$ See Ulen, 1984.
} 


\section{B. Enforcement Costs}

High bargaining costs combined with foreseeable enforcement costs will prevent many contracts from being made. Enforcement costs too are due in part to inherent measurability problems. Even if internally observable, actions may be unobservable to third parties such as judges or arbitrators. Courts may also be corrupt or arbitrary basing judgments on political or personal criteria. Parties may be able to use seemingly legitimate arguments to breach contracts opportunistically when it is in their interests to do so. The law is faced with the constant challenge of devising clear rules that discourage fraudulent and deceptive contracts while encouraging the general formation of wealth enhancing and risk reducing contracts. An efficient legal rule must follow a cost-benefit criterion: Is the value of the mistakes it prevents (the benefits of the rule) greater than the value of the potentially valuable contracts is discourages. In addition there must not be any other substitute rule (or set of rules) which will produce greater net benefits.

Thus the law should not enforce contracts which involve fraud, duress and incompetence and should ideally not enforce contracts which involve deception, whether deliberate or because of nondisclosure of relevant information. But it may be hard to determine whether these conditions are met and it is possible that courts will go too far in granting such claims, thus weakening the position of contracts in general. $^{21}$ The exact boundaries that should be associated with the application of legal rules are difficult to specify in an exact manner. Nevertheless for developing countries which have less literate and less commercially sophisticated populations, and weaker information gathering institutions, a stricter enforcement of routine contracts but a weaker enforcement of complex contracts full of potential "unfair surprises" may be more appropriate. ${ }^{22}$ The greater uncertainty in the political and economic environments of developing countries might make the strict enforcement of contracts both unfair and administratively costly. The reliance on informal arbitration mechanisms based on local cultures may be more appropriate in many contexts, though more formal enforcement may be required as the level of development expands.

\footnotetext{
21 Richard Epstein, for example, believes that courts should not expand the doctrine of unconscionability too far and should use it only insofar as it facilitates protecting parties against fraud, duress and incompetence by not requiring as much evidence to prove these transgressions. To Epstein, too wide an application of the unconscionability doctrine will result in the non-enforcement of many legitimate contracts and hence the prevention of many future mutually beneficial contracts. Epstein, pp.292-293.

${ }^{22}$ Melvin Eisenberg, pp. 301-.
} 


\section{Firms and Markets}

Hold-up problems and possibilities for opportunism become multiplied with more complex multiperson contracts involving large numbers individuals requiring them to undertake a great variety of tasks and specific investments. Such complex contracts are often necessary to take advantage of the benefits of specialization, teamwork and the economies of scale and scope made possible by existing technologies. Sometimes resource owners may be able to overcome these transaction costs by establishing private organizations such as firms [Coase 1937; Williamson 1985]. The firm may be considered as a complex "nexus of contracts" wherein resource owners agree to follow a certain set of rules and to submit to a certain governance or authority structure[Alchian and Demsetz 1973; Jensen and Meckling 1976; Williamson 1985]. The "owners" are the so-called residual claimants of the firm, putting their own capital at risk. As owners they get to decide on how the resources under their control are to be managed [Hart 1989]. By forming such organizations resource owners will be able to overcome some of the specific transaction costs associated with pure market exchange. According to Vanberg [1994], when individuals join a firm, or any organization, they agree not to an exchange of goods and services but to an exchange of commitments to accept certain constraints on their future behavior. ${ }^{23}$ Similarly Kreps [1984] defines a firm by the principles it chooses to guide its responses to unforeseen contingencies. These principles and how they are implemented define the "culture" of the firm and are designed to instill trust in employees who are asked to accept a hierarchical authority structure when joining the firm.

An individual has authority if she can direct others to undertake a range of actions they would not undertake on their own initiative [Simon 1951]. Some kind of authority structure is required to coordinate the activities of the various members of a firm. If there is one owner she may represent this coordinating authority. The owner may direct employees to various tasks, monitor their actions, and determine their contracts. In a small organization these functions, and the reciprocal trust of employees that authority will not be abused, may be relatively easy to achieve. But to take full advantage of teamwork, specialized investments, and economies of scale, larger and more complex organizations are often necessary.

\footnotetext{
${ }^{23}$ Viktor Vanberg, 1994, p. 140.
} 
To establish such enterprises it may be necessary to combine the capitals of a number of individuals. This can be done by pooling capital in a partnership or borrowing the needed capital. Forming partnerships among many people creates the familiar incentive problems associated with common ownership. In addition, if the firm borrows money all partners will become fully liable for the entire firm's debts, significantly increasing the risk to each partner in the event of bankruptcy. Thus limited liability and security laws allowing the formation of corporations may need to evolve.

For equity and credit markets to work effectively, sophisticated and uncorrupt monitoring and enforcement mechanisms are required. Without such controls some shareholders might be able to divert funds to their own uses while debtors may be induced to take undue risks or practice outright corruption at the expense of creditors.

When ownership is widely shared, a manager may be hired by the owners to coordinate the activities of the firm, monitor the performance of employees and make necessary contracts with those outside the firm. A centralized governance structure will need to be established. The distinguishing characteristic of a governance structure is that selected agents are given discretionary authority to direct resources including employees to undertake tasks not specifically listed in a contract. Labor contracts in particular are always incomplete, implying that the employer will have discretionary power within specified limits to direct the employee. Governing a firm, as with any organization, involves certain kinds of transaction costs that are different from the transaction costs associated with market exchanges.

Discretionary authority over internal firm resources implies that bargaining costs will be lower than if market contracts had to be made with each individual resource owner at every moment in time. But the costs of monitoring employees and obtaining information about aspects of the production process may be higher [Milgrom and Roberts 1990]. These particular measurement problems mean that the employees in various positions in the hierarchy of the firm may try to gain private advantage by misrepresenting information or otherwise misusing their discretionary authority.

\section{Influence Costs}

Milgrom and Roberts refer to such potential private misuse of authority as influence costs and provide the following classification of these costs. First, managers may be able to directly misuse their 
authority for private gain, a result of the so-called principal-agent problem. Second, given that relevant information for efficient decision-making is dispersed throughout the organization, lower level employees may try to influence the decisions of managers in a self serving fashion by providing misinformation. Third, owners and managers will attempt to control these influence activities by expending some of the firm's resources. The time and effort that goes into influence activities takes away from potentially productive activities. Thus corruption and the effort to restrain corruption within the organization are part of the costs of central management. ${ }^{24}$ One of the objectives of owners in establishing the rules and procedures of the firm involves finding ways to separate influence activities that are harmful, that distort and waste resources, from those that are productive. Of course, the procedures may also be designed to perpetuate the influence and discretionary power of the owners or managers. ${ }^{25}$ It might be noticed that the imperfect information that gives rise to influence costs is the root cause of all incentive problems associated with organizations (as indeed it is of all common governance situations) including, most importantly, that of government.

Without appropriate legal foundations, efficient-sized firms are unlikely to be formed. But the necessary legal institutions are themselves most often the product of government action which is itself subject to influence costs. Governments may enact rules that are predatory toward private enterprise or serve special interests with political power. Rules may also be established for perfectly legitimate reasons but be used in perfectly illegitimate ways. Many developing countries, including most countries of the Middle East, suffer from governments that have become too large, promulgating too many rules and regulations, regulations that become inefficient in their implementation. Governments tend to make property rights of large enterprises insecure through various forms of arbitrary exactions and changes in regulations. Thus in these countries firms tend to be small and localized, and based primarily on personalized exchange relationships. Such personal exchanges have low transaction costs but the costs of actual production are high because the gains from specialization are not realized. More sophisticated contracts involving larger firms and the potentially low production costs of such firms are not realized because the insecurity of property rights and contracts makes transaction costs too high. As indicated by

\footnotetext{
${ }^{24}$ Ibid. pp. 80-.

${ }^{25}$ See Marglin 1974 and Edwards 1979.
} 
North, "Non-specialization is a form of insurance when the costs and uncertainties of transacting are high. ${ }^{26}$

In many developing countries production occurs in small craft shops with low fixed costs operated by a master craftsman with perhaps one or two apprentices. Products are non-homogeneous, creating high measurement costs and uncertainty for potential buyers. Potential entrepreneurs who establish small firms with a minimal number of workers are faced with various constraints if they wish to expand. First is the very limited access to capital, a consequence of imperfect capital markets. Capital markets are particularly sensitive to the problems of asymmetric information and high transaction costs, and thus prone to fail in environments without the appropriate legal and regulatory institutions. Banks are often state-owned and obtaining loans for expansion involves a political process which can be cumbersome and costly. Industrial firms in developing countries are invariably dependent on imports of vital inputs, such as machinery and equipment. Access to imports is often uncertain and problematic due to uncertainty about government policy with respect to import licenses, import taxes and access to foreign exchange. Often it is necessary to have political connections to be able to import at predictable cost the inputs needed for sustained production. In addition, larger firms generally are subject to more strict enforcement of labor laws involving the provision of health insurance and restrictions on their rights to discharge workers. Potential entrants into the formal sector may be subject to high minimum capital requirements making it difficult to start up a business. ${ }^{27}$ These and other limitations on the growth of firm size tend to mean that firms will use little fixed capital and will eschew contracts that are long term. Many firms will be driven into the informal or extra-legal economy. The only large scale enterprises viable in such an environment will be those politically supported or directly operated by the government. ${ }^{28}$

\section{Government Regulation and Public Ownership}

It is clear that governments play a major role in determining the kinds of economic activities that are undertaken in society. The transaction cost- property rights framework discussed above can be used to

\footnotetext{
${ }^{26}$ North, 1990, p. 34.

${ }^{27}$ According to the World Bank's Doing Business in 2004, Middle Eastern countries have the highest minimum capital requirements while Latin American nations have the most rigid hiring and firing rules. ${ }^{28}$ Ibid. p. 65.
} 
discuss the appropriate role of government under different circumstances. Government is by definition a set of organizations that impose rules and enforce them. Government is necessary to protect property and contract, to provide overall rules to regulate the use of common resources, to provide regulations to control commercial activities that may harm the general public (externalities and monopolies), and to provide services which markets and private firms and organizations will not provide, or will provide inefficiently if left unregulated.

The government can be conceived as a hierarchical authority structure with multiple agendas. As a result it will suffer from all of the potential influence (or "rent-seeking") costs associated with large organizations but on a much magnified scale. Individuals and groups in society will try to influence government decision-makers to pass laws or perform tasks that will benefit them personally, often at the expense of others, all under the pretext that the public interest will be served. They will claim that these government actions will prevent private sector inefficiencies (fraud, monopoly, externalities, and imperfect information problems) or that government services are needed because the private sector cannot provide them efficiently. The effects are often exactly the opposite of what is claimed.

Because of these influence activities, governments are often too large with intrusive and unnecessary regulations in some areas even as other areas are left unregulated and ripe for private sector fraud and monopolization. Many enterprises will be driven into the underground economy operating under their own evolving extra-legal rules and norms [DeSoto 1989 and 2000]. The firms that remain in the formal sector will be bogged down trying to comply with or circumvent the cumbersome rules of the bureaucracy. Only those firms with influence and political connections will be able to do well in this environment. Often the government ends up undertaking the direct production of goods and services that would have been best produced by the private sector, even as the production of needed public goods is ignored.

An important point to note is that there is no unique size of government. It is how government does what it does, rather than the scale of its activities, which helps determine the productivity of an economy. ${ }^{29}$ Does the government provide the regulatory mechanisms to prevent fraud and monopolistic

\footnotetext{
${ }^{29}$ Size of government however may be an imperfect proxy for inefficient government since larger size increases the probability that the government is undertaking tasks that would be best left to the private sector.
} 
practices, and to reduce transaction costs, or do its actions contribute to and increase these harmful practices and costs? Well functioning markets generally require sophisticated regulatory mechanisms and some kind of social safety net to protect those exposed to inevitable market volatility. Failure to provide these regulations and safeguards may lead to major market failures and political disturbances. ${ }^{30}$ The lack of adequate regulatory institutions may have been responsible for what Rodrik [1999] calls the "dismal failures" of privatization in Russia during the 1990s. Russia's privatization during the 1990s was carried out hastily and without sufficient government regulation, and thus led to widespread monopolization, corruption and inefficient (and unfair) market outcomes. Similarly the absence of adequate social safety nets may have been the cause for the backlash against price reforms in Latin America during the 1980s. ${ }^{31}$ Capitalism can only thrive if there is some trust in government institutions and confidence that the regulatory apparatus will work effectively. Unstable regulatory environments invite corruption as different groups invest in rent seeking or influence activities in an attempt to subvert regulations in their own favor. In cases where the regulatory mechanisms are weak, private groups might even invest in private enforcement of their own rules or in attempts to buy off state officials and judges.

Glaeser et al [2002] argue that the degree of corruption and regulatory uncertainty might also be due to inequalities of wealth. Inequalities of ownership of resources allow the rich to manipulate government institutions, including government agencies, legislatures and the judiciary, to obtain favorable laws, regulations and interpretations of regulations and laws. ${ }^{32}$ In such cases those without influence will be unlikely to be able to raise capital or want to invest because their investments will be subject to regulatory expropriation. In such circumstances, investment will be undertaken only by small influential elites. ${ }^{33}$ DeSoto's proposal for legitimizing the "informal" sector, by giving formal property right protection to squatters and informal businesses operating outside the current legal system, may help in this regard by reducing inequality, promoting legal competition and bolstering the rule of law (so long as steps are taken to prevent a "race for property rights" as new squatters flood into public or unclaimed properties).

\footnotetext{
${ }^{30}$ Rodrik, 1999, p. 7.

${ }^{31}$ Ibid. p.2.

${ }^{32}$ Glaeser, Scheinkman and Shleifer, 2002, p. 2. They cite studies by Alesina and Rodrik (1994) and Persson and Tabellini (1994) which indicate that inequality tends to reduce growth. See also Keefer and Knack [2000] and Rajan and Zingales [2003].

${ }^{33}$ Ibid. p.4.
} 
Economies dominated by corrupt private elites are inherently unstable and susceptible to the emergence of populist movements. Political entrepreneurs might be able to use the discontent with the existing elites to implement redistributive policies toward the poor. ${ }^{34}$ This, in turn, will destabilize the private sector, especially its more transparent, organized segment. Large enterprises might in fact be taken over by the state and run as state owned enterprises perhaps to prevent monopolistic abuse or perhaps to protect employees of the firm. Managers may be chosen on the basis of political patronage rather than managerial expertise. Losses by firms may be covered by the government budget. None of this is conducive to productive investment.

\section{Government versus Private Ownership}

The question of government or private ownership of large enterprises presents a major dilemma for developing countries. It is commonly agreed that the government should provide public goods, merit goods, other goods with large positive externalities, goods that are natural monopolies, and goods which the private sector might not provide competitively. Having decided on government provision, a decision has to be made about whether the good or service should be provided directly "in-house" by government employees or indirectly through government contracts with private contractors. Shleifer [1998] wants to use current theories of ownership and contracting to answer this question. Such an analysis might provide the theoretical rationale for privatizing state operated firms such as steel, energy, telecommunications and financial services that has taken place in many developed and developing countries over the past 20 years. Note that many of these industries were originally state operated because they were considered natural monopolies or it was felt that the private sector would not be able to raise sufficient capital due to imperfect and severely underdeveloped capital markets.

Consider first the case of a government that is benevolent, knows exactly what it wants to accomplish and is able to specify its multiple dimensions in a contract. If such a complete contract could be devised, negotiated and enforced at zero cost, there would be no difference between direct government provision and contractual provision. This follows from a simple application of the Coase theorem to government contracting. But in all real world situations such complete contracts and regulations cannot be

\footnotetext{
${ }^{34}$ See the interesting recent works by Amy Chua [2003] and Rajan and Zingales [2003].
} 
written and enforced due to the measurement and verification problems discussed previously. Whether direct government provision or government contracting is more efficient depends in large part on the significance of these "non-contractible" quality dimensions [Shleifer and Vishney 1997; Shleifer 1998].

Private ownership of assets provides better incentives for investments to improve productivity and lower costs. Innovations and quality improvements will also be more forthcoming so long as they are observable to government agents responsible for monitoring the contract and so long as the profits from these actions are not usurped through further government regulation and renegotiation. ${ }^{35}$ If the political system is perceived to be unstable and subject to stochastic regulatory changes, private incentives will be weakened and government ownership may become more attractive. Even in a stable regulatory environment the cost cutting incentives of private ownership may adversely affect those aspects of quality which are unobservable or unverifiable [S\&V1997]. Here "strong incentives may lead to inefficient outcomes and soft incentives might be better. ${ }^{, 36}$ Government management's lower incentives to hold costs down may actually be a good thing in this context. Shleifer [1998] argues, however, that even with these conditions private ownership might still be preferred if innovation is an important component of the industry and the value of innovations can be observed ex post. Similarly if some competition can be introduced into the system, perhaps from imports, or if consumers are able to judge quality and resist purchases of mediocre products or services, then the incentives for inefficient cost reduction will be less. ${ }^{37}$

Thus government contracting with private producers is to be preferred if four conditions are met. First, the opportunities for unobservable quality reductions must be low. Second, innovation must be an important consideration. Even though it seems that innovation is always important, its importance varies with the nature of the product and the technological potentialities associated with the product or service. Of course it might not be easy to determine ex-ante which products have technological potentialities. Third, the potential for competition and hence the ability of consumers to effectively discipline the producers must be relatively high. And fourth, creation and maintenance of reputation must be an important consideration for the managers of private firms with government contracts. ${ }^{38}$

\footnotetext{
${ }^{35}$ Shleifer, 1998, pp. 133-137.

${ }^{36}$ Ibid. pp. 137-138.

${ }^{37}$ Ibid. p. 139.

${ }^{38}$ Ibid. p. 140.
} 
Of course government objectives are not always benevolent and the possibilities for influence activities mean that the decision-makers of government agencies might be susceptible to doling out government contracts to influential political supporters. But under such circumstances privatization might also be susceptible to corruption. If the state is corrupt due to too much influence activities, it will be a bad producer but also a bad regulator and privatizer [Djankov el al 2003]. In summary, privatization of state owned enterprises may lead to more efficiency and reduced corruption only if there is a strong and accountable regulatory apparatus, including anti-trust, in place, strongly supported by commonly shared political beliefs and cultural norms. If these formal and informal institutions do not exist, the process is likely to lead to monopolization and corruption. Even more corruption may result if new private owners gain influence over the government's imperfect regulatory apparatus through bribes and favors.

\section{Culture, Religion and Property Rights}

Legal rules, property rights, and contract law are more easily implemented and enforced if the general public is aware of them and places some credence in their moral validity. Under such conditions, the fairness of activities is more easily accepted, and disputes and violations of property rights are less likely. Much current research shows that laws that are compatible with local norms are easier to enforce with higher levels of compliance and fewer disputes. ${ }^{39}$ It seems reasonable to conclude that where possible written law should be in conformity with social norms. ${ }^{40}$

But what happens when there is a conflict between local norms and the needs of a complex market economy? In such cases, laws may have to deviate from norms to some extent. Fortunately social norms are rarely unidimensional and rigid. The multiplicity and interpenetration of beliefs and customs creates some flexibility in norms and the possibility for change over time. Thus "good laws" can serve as foundations for new norms, just as good norms can serve as the foundation of good laws. ${ }^{41}$ There is a continuous interaction between formal public rules (laws and regulations) and the rules created by non-state actors (social norms and conventions). Religion is the basis of many norms in society providing an ethical foundation for behavior. Much of the common law and civil codes of developed countries is based on the

${ }^{39}$ See Buscaglia and Ratliff, 2000; Djankov et. al. 2003; DeSoto, 1989 and 2000.

${ }^{40}$ See also K. Mechlum, pp. 328-330.

${ }^{41}$ Ibid. p. 330. 
ethical codes emerging out of religious beliefs. Nevertheless, in developed countries a tradition of law and courts independent of direct religious intervention has evolved. Thus their legal traditions have developed a greater flexibility in coping with modern commercial and industrial conditions. ${ }^{42}$

In developing countries legal systems are generally not as well developed. Many countries have transplanted laws from western, more advanced, countries. This might be a low cost way of developing a legal system, but such transplantations often require a long process of developing the human and institutional capacity to implement and enforce the laws. The public must understand the law, and lawyers, prosecutors and judges must be trained. Such a process might be quite costly, especially if there is resistance among various groups about accepting the legitimacy of the new transplants. The potential conflict between domestic cultural norms and externally derived laws may be illustrated by a brief look at the struggles for legal legitimacy in many Islamic countries.

\section{Legal Legitimacy in Islamic Countries}

In recent decades, a revival of religious feeling in many parts of the Islamic world has increased demands among many that the Sharia, or Islamic law, should replace existing legal systems that in many cases are thought to be based on legal transplants and non-Islamic precepts. Opponents of this view feel that the Sharia will offer too rigid a code, incompatible with modern commercial and financial requirements, or that it is too ambiguous to serve as a basis for modern law. Many of these controversies are similar to what took place in the West before the advent of the modern era. But it may perhaps be easier for Islamic doctrine to adjust to the legal requirements of complex modern economies. The Sharia, for example, provides a somewhat sophisticated body of commercial rules which may act as a foundation for commercial law. Lawmakers in Islamic countries may be able to benefit from such a foundation without succumbing to "hard line" interpretations of the law.

The Sharia has rather complex rules about ownership and contract and, as is the case with all systems of law, interpretations of the substance of these rules have frequently been in conflict, allowing a measure of flexibility in the evolution of the legal systems based on them. All bodies of law are always

${ }^{42}$ For now we ignore the debate over the relative efficacy of common law systems versus civil law systems. 
incomplete and potentially contradictory inasmuch as precise and unambiguous rules for all contingencies can never be written. As circumstances change, reinterpretations and adjustments are always made through commonly accepted procedures. In the case of Islamic law there are many established procedures within the religious institutions of different countries for interpreting laws, resolving disputes and establishing authority. The sharia was historically developed in a commercial environment and is thus quite sensitive to the requirements of commerce. As such, it may provide a good normative foundation for the legal system of countries whose populations are prone to see Islamic-based laws as more legitimate than legal transplants from abroad. Sometimes legal transplants can be made compatible with sharia law. This was what was attempted in Iran during the Reza Shah period (1921-1941) when a civil code was introduced which attempted to codify the law but make it consistent with customary and Islamic law. That attempt seemed to have been a success at the time even though many religious figures decried the perceived secularization of the law and later, after the Islamic Revolution of 1979, tried to replace the civil code with a more hard-line Islamic version, something they have not been entirely successful in doing.

The Sharia recognizes various forms of property and places restrictions on each. Private property (melk) is recognized in the sense of a complete and exclusive right to use or dispose of a resource so long as it does not significantly harm other properties. ${ }^{43}$ Different kinds of usufructs and how they can be disposed are defined. Legitimate and illegitimate means of obtaining possession are recognized. For example, legitimate ownership can be obtained by the cultivation of "dead lands," through contract and by inheritance or bequest. Theft and usurpation would be illegitimate ways of acquiring property. Property legitimately acquired cannot be arbitrarily expropriated. Of course, in unstable political environments, such as the period after the Iranian Revolution, legitimacy of acquisition could be used as a pretext to destabilize the entire system of existing property rights.

Resources which have no ownership are described including public property (melk al-amma) such as the air, waterways and public roads. According to Schacht "everyone is entitled to use (public property) in a way which does not cause prejudice to the public." ${ }^{44}$ The importance of these public resources is recognized and given much attention in the sharia. An example may be the stipulations with respect to water. According to Islamic law water cannot be bought and sold, but the channels through which the

\footnotetext{
${ }^{43}$ See Schacht, pp.134-143.

${ }^{44}$ Schacht, 1964, p. 136.
} 
waters flow and the right to use it may be sold. ${ }^{45}$ The restriction on the sale of water is traced to a saying of the Prophet. An Islamic jurist, Abu Yusuf interprets this prohibition to apply only to water that has not been placed in a receptacle. The resource water comes from various sources including big rivers, smaller rivers, canals and underground aquifers. Big river water is theoretically open to all. Canals may need to be dug to irrigate lands but the amount of water diverted may be limited to the extent that it harms the positions of other lands. Priority and restrictions on use may be placed based on circumstances and needs. ${ }^{46}$ Islamic law also recognizes an important category of property known as waqf or pious foundation. Properties are removed from private ownership and made inalienable with their revenues devoted to some public or charitable purpose including the support of mosques and religious schools. Waqfs may even be established to support the descendents of the founders. Waqfs are managed by agents called mutavallis appointed by the founder or his beneficiaries and overseen by reputable clerics. Mutavallis are paid out of the profits of the waqf and are considered to have a fiduciary responsibility to carry out the wishes of the founder. Detailed rules exist for how waqfs should be administered, how its revenues are to be used and even how changes can be made in the use of revenues in case the original intent of the founder becomes invalidated or socially useless [Kuran 2001]. Evidently much thought has been given to the principal-agent problem in the administration of waqf properties. Nevertheless the possibility of dissipation and misuse always exists in situations where the actions of agents cannot be easily observed or verified.

Historically many waqf were established by wealthy individuals for a variety of reasons. Establishing waqfs enhanced the social prestige of the founders and increased their reputations for piety and trustworthiness. Waqf would be less likely to be confiscated and helped shelter the other assets of the founders from potential confiscation by present or future rulers. Establishing waqfs may also have been a way for influential people to legitimize their ill-gotten gains. ${ }^{47}$ By reducing the probability of confiscation, expected returns from investments in other properties would be increased and investment in these other properties would likely increase, but investment in the waqf property could go up or down depending on a variety of circumstances. Kuran believes that the prevalence of waqf in many Islamic societies during the

\footnotetext{
${ }^{45}$ A. K. S. Lambton, p. 210. Lambton's monumental work on landlord-peasant relations during the course of Iranian history provides an invaluable source of information on the richness and complexity of property rights in Iranian agriculture.

${ }^{46}$ Ibid. pp. 211-212.

${ }^{47}$ Kuran, pp.16-20.
} 
period of European expansion may have "locked up" too many resources and hindered the growth potential of those societies by preventing sale and transfer and thus the pooling of resources to take advantage of economies of scale and scope made possible by changing commercial and industrial possibilities. In addition the inflexibility in the mission of the waqfs may have contributed to the perpetuation of activities which had long outlived their usefulness and social productivity.

During the $19^{\text {th }}$ and early $20^{\text {th }}$ centuries governments seeking more revenues and political control tended to confiscate more waqf properties and placed important waqf under government supervision. ${ }^{48}$ Nevertheless the Waqf has remained an important category of property. Though they are no longer the main provider of public goods (this function having been taken over by municipal and central governments) waqf are still established to support charitable causes including relief to the poor, the provision of nointerest loans to the needy and support of hospitals, mosques and Islamic schools. The concept of waqf has been expanded to include financial assets and provides for the pooling of the financial assets of large numbers of people in pursuing given public purposes. Waqfs are similar to non-profit organizations in western countries pursuing missions that pure profit maximizing firms might not pursue as well. They serve a useful social function and may even be a means to promote civil society by taking assets outside of the taxing authority of the government and designating revenues to purposes not necessarily encouraged by government.

The Sharia also has well developed rules relating to commerce and contracts. Here a principal concern seems to be a desire to prevent dishonest and unjustified enrichment. Many of these restrictions also exist in different variations of Western law. Here too the conditions under which contract may be considered illegitimate and thus unenforceable are spelled out. The increasingly broad interpretation of the doctrine of unconscionability in American law has greatly expanded the extent of prohibited or unenforceable contracts. In Islamic law too there is great concern about preventing fraud and duress and other ways in which one party may take advantage of another party. Note that while these prohibitions seem designed to promote justice, they may also have an efficiency rationale if properly interpreted. The prohibition against usury (reba) in the Sharia is one prohibition which existed in early Christian doctrine but which is now so narrowly defined in Western law that it is no longer a constraint for credit and

${ }^{48}$ Ibid. p. 61. 
commercial transactions. This seems to still be a problem for countries that wish to follow the Sharia. Nonetheless Islamic scholars and bankers and merchants have devised many ways of getting around this prohibition.

Contracts that involve reba or interest are considered to be illegitimate or haram. This simply means that there should be no reward for time preference under risk-free situations. This does not necessarily mean that credit markets cannot function. The creditor must become a partner with the debtor. Thus he may share in the profits and losses of the enterprise undertaken by the borrower. The concept of a sleeping partnership (mozaraba) can be used to circumvent the prohibition against reba as have many types of complex and somewhat obscure implicit contracts. ${ }^{49}$ Interest has also been justified by some Islamic scholars as a compensation for service. ${ }^{50}$ In practice different financial instruments have been created that effectively allow the earning of interest by banks and their depositors. The question that can be legitimately asked is whether the special contracts needed to get around the prohibition against reba increase transaction costs to a degree that significantly reduces the performance of capital markets. North believes that breaking down the prohibition against usury in Western countries was a major factor in the development of modern capital markets. ${ }^{51}$

Contracts should also be free of excessive risk (gharar) and gambling or pure speculation (ghemar). Islamic scholars have identified the specific conditions for each of these which would make a contract void. Contracts should also be free from manipulations and the creation of artificial shortages due to hoarding (ehtekar). Transactions should be free of misrepresentation and information vital to a transaction must be revealed. All these conditions may be interpreted in ways that are consistent with the norms of economic efficiency. ${ }^{52}$ In particular, there is the doctrine of maslahah or "necessity" (the principle of the supremacy of the public interest) allows interpretations of the law and regulations which serve the interests of the Islamic community. Many liberal Islamic scholars have advocated using the

\footnotetext{
${ }^{49} \mathrm{C}$. Geertz discusses the pervasive role of credit in the Moroccan bazaar. Almost all exchanges involve some kind of credit even though the terms are often hidden in complex negotiations over prices and qualities. "Although the Islamic prohibition against usury normally removes an open interest rate as a possible item of negotiation, it certainly does not remove a concealed one, and the interaction of credit balances and money prices is an intricate matter, subject to a very high level of moral nuance and commercial artfulness." Op.cit., p. 223.

${ }^{50}$ H. Enayat, p. 78.

${ }^{51}$ D. North, p. 125.

${ }^{52}$ See Mohammed Obaidullah, "Islamic Risk Management."
} 
doctrines of maslahah, talfiq (or synthesis) and ejtehad (or learned innovation) for interpreting the Sharia in a way as to make it consistent with "modern" commercial requirements. ${ }^{53}$ The point is that there is enough flexibility to make the laws compatible with efficiency norms. In particular if such rules are understood by the public and acceptable to them, then enforcement costs will be lower than otherwise and trade, specialization and the formation of the special contracts necessary to form productive organizations can be facilitated.

\section{Empirical Applications}

The framework presented in the preceding sections is in the tradition of the new institutional economics and law and economics. In this framework institutions are defined as the informal and formal rules (or norms, customs, laws and regulations) specifying, enforcing and restricting the rights and obligations of individuals with respect to specific resources. Institutions determine the constraints faced by individuals and therefore structure their incentives to undertake productive or predatory actions.

This theoretical framework predicts that "good" property rights institutions will reduce the transaction and production costs associated with productive activities leading to increased investment and growth while "bad" property rights institutions will increase these transaction costs and push resources into socially unproductive and defensive uses. In general terms improvements in the quality of property rights (both the clarity of those rights and their enforcement) will reduce the costs of productive actions and promote efficient investments through various interconnected channels.

The challenge, of course, is to go beyond general statements on the growth-enhancing nature of property rights and to test this theoretical framework in a variety of concrete contexts. Has the empirical literature been up to this challenge? Many illuminating empirical studies have been undertaken to discover the exact importance of different institutional arrangements on investment and growth. These studies may be classified into three categories and will be discussed below.

\footnotetext{
${ }^{53}$ H. Enayat, p. 78.
} 


\section{A. Cross- Country Studies Using Aggregate Indices}

The first category of studies uses different aggregate indices of institutional quality and economic performance to econometrically estimate the importance of institutions. Many of these studies have been concerned with trying to determine the relative importance of institutions as compared to economic policies or geographic endowments [Rodrik et al 2002]. Before the different influences could be sorted out, reasonable indices or proxies for institutional quality, good policy, and geographic endowment had to be obtained..$^{54}$ These proxies by necessity are always somewhat arbitrary, perhaps based on surveys and perceptions, making it difficult to identify all of the complex causal relations among different variables. Despite this Rodrik et al [2002] have effectively demonstrated that institutional quality (measured in different ways) is highly correlated to different measures of economic performance including GDP per capita, growth and growth volatility. They also find that there is an important correlation between good policies (such as greater openness to international trade, stronger domestic competition and stable macroeconomic policies) and good institutions. The sustainability and economic effects of good policies seems to depend on good institutions. Institutions are thus more important than policies or geographical endowment in determining growth. In fact, policies did not seem to have any independent influence on growth, and "geography" seemed to have weak effects. The effectiveness of good policies seemed to depend on the existence of good institutions. Institutions, on the other hand, were an independent determinant of performance and not simply the consequence of higher incomes or better policies. ${ }^{55}$ Easterly and Levine [2002] obtain similar results from their econometric analyses. Geographic endowments seem to affect performance only through their effects on institutions while policies do not have any independent effect on income or income growth [IMF 2003]. These studies provide some general confirmation for the institutionalist theory. Nevertheless, the results should be interpreted with caution due to aforementioned measurement problems associated with finding adequate proxies for the various theoretical variables and the econometric problems associated with disentangling the complex causal relations among the variables.

\footnotetext{
${ }^{54}$ See Rodrik et al, 2002; IMF World Outlook 2003; and World Development Report 2002. The IMF 2003 chapter 7 has a compact summary of many of these studies.

${ }^{55}$ Rodrik et al, p. 4.
} 
The empirical findings just discussed tell us little about what the actual optimum structure of property rights should be. As should be clear by now, a property rights regime consists of more than just the protection and enforcement of private property rights. Different property rights regimes might produce equally good (or bad) results under different political and cultural circumstances. For example, during the 1990's Russia's economy performed relatively poorly compared to that of China, even though Russia had instituted a legal regime based mainly on private property rights while China still had a legal system with many fundamentally socialist features. Nevertheless the relative absence of predictable judicial enforcement in Russia meant that private investors felt insecure whereas the Chinese government seems to have provided sufficient protection to encourage large investments by private entrepreneurs. Similarly, good performance seems to be possible under different institutional structures. The institutions of advanced high income countries still have major differences in terms of the role of the public sector, the nature of the legal systems, the types of corporate governance or the social insurance mechanisms that prevail. ${ }^{56}$

\section{B. The Comparative Institutional Approach}

A second approach used to understand the impact of institutions is the comparative institutional approach which tries to take advantage of what may be called historical experiments to demonstrate the relative importance of different institutions in particular circumstances. Two or more countries with similar initial economic, political and legal conditions may have pursued different paths with respect to specific aspects of their overall institutional structure. The more similar the initial situations the more reliable the comparisons may be. Johnson and Shleifer [1999] use this method to support their hypothesis that stronger regulatory mechanisms will often improve outcomes when the costs of private litigation are too high due to difficulties of verification (of fraud) and incompetence or corruption of courts. They show how different regulatory approaches affected the performance of securities markets in the Czech Republic and Poland. These countries had similar historical and geographical situations. Both had similar communist backgrounds, both were freed at about the same time, and both followed market orientated policies beginning in the 1990's. By carefully describing the similarities and trying to control for relevant differences (for example by explaining why particular differences would be irrelevant to the effect they

\footnotetext{
${ }^{56}$ Rodrik et al, p.22. See also Glaeser and Shleifer 2003.
} 
were trying to measure) Johnson and Shleifer show that the stricter regulatory system established in Poland was more successful in preventing fraud and corruption than the freer, less regulated system established in the Czech Republic. They conclude that when the legal system is weak and the transaction costs of private agreements and private litigation are high, it may be more appropriate to have strong regulatory agencies overseeing certain markets to ensure that consumers (shareholders and creditors in this case) are not defrauded. They thus support the theory that under certain circumstances, regulations which restrict the range of allowable contracts, may actually improve the market and expand private opportunities for making valuable investments.

Similar comparative institutional analyses are carried out by DeSoto and his colleagues at the Instituto Liberdad y Democracia. Their thesis is that unstable regulatory environments and the absence of effectively enforced "formal" private property rights (that is, "bad" institutions), will lead to much unproductive rent-seeking and protective activities and inefficient investments. These studies devote considerable effort to measuring the costs of earning a living or doing business according to the complex maze of regulations imposed by the government. They show that these unreasonable costs force people into the "informal" sector which operates according to its own rules and customs but is basically inefficient. The lack of formal recognition and protection of property rights leads to great inefficiencies despite the great pool of talent and potential wealth that exists in the informal sector. Those who control assets informally will not make long term investments and cannot use their assets to form complex and long term contracts with others.

\section{The Micro-Econometric Approach}

The last approach we will discuss is what may be called the microeconomic- econometric approach. Microeconomic models are created showing the various channels by which property rights affect investment. These models are then estimated and tested econometrically. Besley's [1995] impressive study of the importance of private property rights in Ghanaian agriculture is indicative of this micro-econometric approach. Besley builds several micro models describing how changes in property rights, moving from more communal to more private rights, will affect investment by farmers. His models show the different ways private property rights will potentially affect investment: by increasing security against expropriation; 
by allowing land to be used as collateral for borrowing, thus reducing the cost of borrowing and increasing investment; and by allowing the transfer of land to those who value it more. In addition he considers the possibility that private rights might be endogenous in the sense that farmers who invest more in their land end up acquiring more permanent and transferable rights. Besley notes that there is no necessary connection between more private rights and investment. For example it is possible that individuals in villages are altruistic towards fellow villagers or that communal sharing rules may allow better internalization of potential externalities. ${ }^{57}$ Communal rights might be just as secure, or transferability rights might not be a significant for improving efficiency. He uses data on two regions of Ghana obtained through surveys of farmers asking them to indicate the various property rights they feel they possess and the investments (such as planting trees) that they have made in a given period on the lands they control. Farmers are asked to indicate whether they have the right to sell, rent, mortgage, pledge, bequeath, or gift their lands, and whether or not they need approval of the lineage in order to exercise each of these rights. From this survey he creates an index of private property rights and proceeds to test his various hypotheses. The results from Wassa County seemed to support the idea that stronger private rights improve investment. The results from Anloga County also showed such a link but the results were not robust and were somewhat inconclusive. Measurement and econometric problems, of multicollinearity and simultaneity for example, could be responsible for this inconclusiveness.

Overall, Besley is unable to find any strong support for any particular theory about how exactly property rights affect investment. In particular he finds little support for the collateral-based argument. His general conclusion is that advocating the creation of greater private property rights should be done with caution and is not a panacea for all that ails "low-growth" agriculture. This ambiguous conclusion is consistent with other studies which show that increases in private rights increase productive investment only when producers have access to complementary markets and communal resources. For example, an empirical study of Thai farming showed that titling (representing an increase in security and transferability of rights) increased investment only when there was access to credit markets. ${ }^{58}$ Of course, titling could in the longer term improve collateralization and thus the emergence of a credit market.

\footnotetext{
${ }^{57}$ Besley, p. 906.

${ }^{58}$ For excellent surveys of the effects of different property rights and contractual arrangements on farm productivity, see the excellent surveys by Deininger and Feder [2000] and Binswanger et. al. [1995].
} 
There are many other scenarios where the expansion of private rights might not promote productive investment. If private rights are created for land while insurance markets remain undeveloped, poorer farmers might be made more vulnerable to risk and thus be induced to take risk-mitigating but productivity-reducing investments. A similar negative impact on investment might occur if politically powerful elites are able to obtain private rights at the expense of small farmers operating within relatively effective communal arrangements involving traditional usufructs. Many studies have shown that larger farms under the control of landed elites are less productive than smaller ones, principally because they will need to rely on hired labor entailing higher monitoring costs. Absence of accessible credit markets and high transaction costs will prevent the transfer of land to more productive (smaller) farmers. In addition, unequal property ownership based on political power usually has other adverse effects on the security of property rights. Landed elites are more likely to be able to induce the government to implement discriminatory laws and institutions favoring themselves and reducing the opportunities of smaller producers. ${ }^{59}$ In fact there is increasing evidence that great inequalities of ownership rights generally weaken overall property and contract rights and thereby reduce the incentives for productive investments [Keefer and Knack 2000]. On a more general level, powerful interests with well established positions in various closed markets might be able to oppose the creation of free market institutions, thereby maintaining their privileged, monopolistic positions. Rajan and Zingales [2003] point to these "incumbent" groups as often opposing the development of competitive financial markets, preferring the repressed financial systems that ration credit to the privileged while denying it to potentially innovative but property-less entrepreneurs.

The growth of private rights might also be harmful if there are possibilities of significant negative environmental externalities. Here, higher private investment might be accompanied by greater overuse of open access or unregulated common resources leading to reduced returns in the future [Lopez 2002]. More secure and transferable private rights might under certain conditions lead to the weakening of the social norms and governance mechanisms controlling the use of common and environmental resources, and thus lower private investment returns. However private ownership rights will have a much more positive impact on investment when credit markets are well developed (or can become more developed because of the

\footnotetext{
${ }^{59}$ Binswanger et. al. pp. 2671-3. It seems that family farms generally have higher productivity than larger farms, in large measure because of the higher costs of monitoring labor in the latter.
} 
possibility of using land as collateral), when governance controls on necessary communal resources are maintained, and where significant environmental externalities are absent. ${ }^{60}$

More theoretical and empirical studies of the types described are needed to discover the complex cause and effect links between property rights, different kinds of complementary (or conflicting) institutions and investment. It is important that measures and proxies for property rights and institutions be based on a realistic theoretical framework that recognizes the complex nature of property rights and the multidimensional ways in which different kinds of property rights can affect incentives for different kinds of productive and non-productive (or redistributive) activities. Such proxies are inherently difficult to construct and must rely on painstaking surveys of the participants or on widely known features of the institutional environment. This is what was essentially done by Besley. With better and more contextspecific data, more accurate tests can be conducted to determine how changes in specific property rights institutions implemented in various cultural and environmental contexts will affect different kinds of investments. Ultimately, which policies and institutions will promote and which will hinder growthenhancing investments will depend on the existing cultural, political and economic circumstances of particular societies. Policies and institutions that are effective in specific societies under particular historical circumstances may not be effective in other societies with widely differing social norms and administrative capabilities.

\footnotetext{
${ }^{60}$ See Deininger and Feder [2000]; and Binswanger et. al. [1995].
} 


\section{Bibliography} manuscript.

Alston, Lee and Bernardo Mueller, 2002. "Property Rights, Violence and the State." Unpublished Cambridge.

Alt, James E. and Kenneth Shepsle, eds. 1990. Perspectives on Positive Political Economy.

Barzel, Yoram. 1989. Economic Analysis of Property Rights. Cambridge.

Batra, Geeta, Daniel Kaufman and Andrew Stone. 2003. Investment Climate Around the World: Voices of Firms from the World Business Environment Survey. World Bank.

Bebchuk, Lucian. 2001. "Property Rights and Liability Rules: The Ex Ante View of the Cathedral." Discussion Paper No. 347, the Harvard John M. Olin Discussion Papers Series.

Besley, Timothy. 1995. "Property Rights and Investment Incentives: Theory and Evidence from Ghana." Journal of Political Economy. 103/5. Oct. 1995.

Binswanger, Hans, Klaus Deininger and Gershon Feder. 1995. "Power Distortions, Revolt and Reform in Agricultural Land Relations," in J. Behrman and T.N. Srinivasan, Handbook of Development Economics. Vol. III. Elsevier.

Press.

Buscaglia, Edgardo and Ratliff. 2000. Law and Economics in Developing Countries. Hoover

Calabresi, Guido, and A. Douglas Melamed. 1972. "Property Rules, Liability Rules, and Inalienability." In Dau-Schmidt and Ulen. 1998.

Chu, Amy. 2003. World on Fire: How Exporting Free Market Democracy Breeds Ethnic Hatred and Global Instability. Doubleday.

Coase, Ronald. 1960. "The Problem of Social Cost” Journal of Law and Economics. 3/1.

Cooter, Robert. 2000. "Three Effects of Social Norms on Law: Expression, Deterrence, and Internalization.” Oregon Law Review. 79/1.

Dau-Schmidt, Kenneth G. and Thomas Ulen. 1998. Law and Economics Anthology. Anderson.

Demsetz, Harold. 1988. Ownership, Control and the Firm, Basil Blackwell.

De Soto, Hernando. 1989. The Other Path. Harper and Row.

De Soto, Hernando. 2000. The Mystery of Capital. Basic Books.

Deininger, Klaus and Gershon Feder. 2000. "Land Institutions and Land Markets," World Bank Policy Research Working Paper No. 2014.

Djankov, Simeon. 2000? "Ownership Structure and Enterprise Restructuring in Six Newly Independent States.” World Bank Discussion Paper.

Djankov, Simeon, and Peter Murrell. 2002. "Enterprise Restructuring in Transition: A Quantitative Survey. World Bank Working Paper. 
Djankov, Simeon, Edward Glaeser, Rafael LaPorta, Florecio Lopez-de Silanes, and Andrei Shleifer. 2003. "The New Comparative Economics." Working Paper. Macmillan.

Eatwell, John, Murray Milgate, and Peter Newman. 1989. Allocation, Information, and Markets.

Edwards, Richard. 1979. Contested Terrain. Basic Books.

Eisenberg, Melvin. 1982. “The Bargain Principle and its Limits.” Harvard Law Review. 95/741.

Ellickson, Robert. 1986. "Of Coase and Cattle: Dispute Resolution Among Neighbors in Shasta County." Stanford Law Review. 38/623.

Ellickson, Robert. 1993. "Property in Land," Yale Law Journal 102/1315, 1993 reprinted in DauSchmidt and Ulen. 1998. Editions.

Enayat, Hamid. 1982. Modern Islamic Political Thought. MacMillan International College

Fischel, William A. 1995. Regulatory Takings: Law, Economics and Politics. Harvard University Press.

Geertz, Clifford. 1979. "Suq: The Bazaar Economy in Sefrou" in C. Geertz, H. Geertz, and L. Rosen, Meaning and Order in Moroccan Society. Cambridge.

Glaeser, Edward, and Andrei Shleifer. 2001. "A Case for Quantity Regulation.” Harvard Institute of Economic Research. Discussion Paper 1909.

Glaeser, Edward, and Andrei Shleifer. 2003. "The Rise of the Regulatory State." Journal of Economic Literature. June.

Glaeser, Edward, Jose Scheinkman and Andrei Shleifer, 2002. "The Injustice of Inequality." Working Paper.

Greif, Avner. 1989. "Reputations and Coalitions in Medieval Trade: Evidence on the Maghribi Traders." Journal of Economic History. 49/4/857-882. 1989.

Guesnerie, Roger. 1989. "Hidden Actions, Moral Hazard and Contract Theory," in Eatwell et. al.

Hardin, Garrett. 1968. "The Tragedy of the Commons.” Science. 162/1243.

Hart, Oliver. 1989. "An Economist's Perspective on the Theory of the Firm." Columbia Law Review. 89/17574. Reprinted in Avery Katz, ed. 1998.

Hart, Oliver, Andrei Shleifer and Robert Vishnay. 1997. "The Proper Scope of Government: Theory and an Application to Prisons." Quarterly Journal of Economics. 112/4/1127-1161.

Hicks, John. 1969. A Theory of Economic History. Oxford.

Holmstrom, Bengt, and John Roberts. 1998. "The Boundaries of the Firm Revisited," Journal of Economic Perspectives. 12/4.

Johnson, Simon, and Andrei Shleifer. 1999. "Coase v. the Coasians.” Working Paper. SSRN. 
Katz, Avery W., ed. 1998. Foundations of the Economic Approach to Law. Foundation Press.

Keefer, Philip, and Stephen Knack. 2000. "Polarization, Politics and Property Rights: Links Between Inequality and Growth.” World Bank Policy Research Working Paper No. 2418.

Klein, Michael, and Bita Hadjimichael. 2003. The Private Sector in Development. World Bank.

Kronman, Anthony. 1978. "Mistake, Disclosure, Information and the Law of Contract." Journal of Legal Studies. 7/1.

Kuran, Timur. 2001. "The Provision of Public Goods Under Islamic Law: Origins, Contributions and Limitations of the Waqf System." USC, Center for Law, Economics and Organization. Research Paper No. C01-13.

Lambton, Ann K. 1953. Landlord and Peasant in Persia. Oxford.

Lopez, Ramon. 2002. "The Economics of Agriculture in Developing Countries: The Role of the Environment," in B. Gardner and G. Rausser, Handbook of Agricultural Economics. Elsevier.

Marglin, Stephen. 1974. "What Do Bosses Do? The Origins and Functions of Hierarchy in Capitalist Production." The Review of Radical Political Economy. 6/33-60.

Mechlem, Kerstin. 2001? "Legal Reform in Developing Countries: The Use of Comparative Law and Law and Economics," in J. J. Dethier, ed., Governance, Decentralization and Reform in China, India and Russia. Kluwer Academic Publishers.

Milgrom, Paul and John Roberts, "Bargaining Costs, Influence Costs, and the Organization of Economic Activity," in Alt and Shepsle, eds.1990.

North, Douglass. 1990. Institutions, Institutional Change and Economic Performance. Cambridge.

Obaidullah, Mohammed. 2000? "Islamic Risk Management: Towards Greater Ethics and Efficiency," International Journal of Islamic Financial Services, 3/4.

Ostrom, Elinor. 1990. Governing the Commons: The Evolution of Institutions for Collective Action. Cambridge.

Ostrom, Elinor. 2000. "Collective Action and the Evolution of Social Norms." Journal of Economic Perspectives. 14/3. Business.

Rajan, Raghuram, and Luigi Zingales. 2003. Saving Capitalism from the Capitalists. Crown

Rodrik, Dani. 1999. "Institutions for High-Quality Growth: What They Are and How to Acquire Them." Draft paper, IMF conference, Nov. 8-9, 1999.

Rodrik, Dani, Arvind Subramanian and Franceso Trebbi. 2002. "Institutions Rule: The Primacy of Institutions over Geography and Integration in Economic Development." Working Paper.

Rose-Ackerman, Susan. 1985. "Inalienability and the Theory of Property Rights." Columbia Law Review. 85/931.

Rosenberg, Nathan, and L.E. Birdzell, Jr. 1986. How the West Grew Rich. Basic Books.

Seabright, Paul. 1993. "Managing Local Commons” Journal of Economic Perspectives, 7/4. 
Schacht, Joseph. 1964. An Introduction to Islamic Law. Clarendon, Oxford.

Shavell, Steven. 2003. "Economic Analysis of Property Law," NBER Working Paper No. 9695.

Shleifer, Andrei. 1998. "State versus Private Ownership" Journal of Economic Perspectives. 12/4.

Ulen, Thomas. 1984. "The Efficiency of Specific Performance: Toward a Unified Theory of Contract Remedies" Michigan Law Review. 83/341.

Vanberg, Victor. 1994. Rules and Choice in Economics. Routledge.

Williamson, Oliver. 1985. The Economic Institutions of Capitalism. Yale.

World Bank, Doing Business in 2004.

World Development Report. 2002. 